\title{
Predictive value of Lipocalin 2 and hyperuricemia on maternal and fetal outcome in pre-eclampsia
}

\section{Diagnostic Study}

\author{
Shahinaz, H.El-Shorbagy', Amira A. Aloraby ${ }^{2}$ and Desouky E. Abo Amo ${ }^{2}$ \\ ${ }^{1}$ Obstetrics and Gynecology and ${ }^{2}$ Clinical Pathology Departments, Faculty of Medicine; \\ Tanta University
}

\begin{abstract}
Background: Pre-eclampsia is a complex hypertensive syndrome that originates in early pregnancy and leads to considerable maternal and fetal morbidity and mortality. Lipocalin 2 is low in healthy human tissue but increased in pathological conditions following endothelial cell injury. Women with pre-eclampsia showed elevated uric acid level in the maternal blood.

Objective: To assess the predictive value of Lipcalin 2 and hyperuricemia on the severity of pre-eclampsia and on maternal and fetal outcome.

Patients and Methods: Sixty women enrolled in the present study were forty affected by preeclampsia and 20 women with uncomplicated pregnancies formed the control group. All women included in the study were subjected to; complete history taking; clinical and blood pressure evaluation; measurements of biochemical parameters and evaluation of maternal and fetal well-being.

Results: Thirty-two of hypertensive women were mild pre-eclampsia having blood pressure $\geq 140 / 90 \mathrm{mmHg}$ but less than $160 / 110 \mathrm{mmHg}$. Eight cases were severe pre-eclampsia with the presence of blood pressure $\geq 160 / 110 \mathrm{mmHg}$. All hypertensive women showed statistically significant increased biochemical parameters compared to control " $p<0.001 "$. Lipocalin 2 and serum uric acid levels in the studied group showed a positive correlation with various biochemical parameters and hyperuricaemia showed a good relation with the pathogenesis of the maternal and fetal manifestations.

Conclusion: Lipocalin 2 could be used as a sensitive indicator of severity of preeclampsia. On the other hand hyperuricaemia showed a good relationship with fetal outcome in hypertensive disorder of pregnancy, identifying those fetuses that are likely to have Intra Uterine Growth Retardation and high perinatal mortality.
\end{abstract}

Key Words: Biochemical parameters, hyperuricaemia, lipocalin 2, predicting, pre-eclampsia

Received: 11 February 2017, Accepted: 26 May 2017

Corresponding Author: Shahinaz Elshorbay, Faculty of Medicine; Tanta University, Egypt, Tel.: 01006700410 , E-mail: shahyshorbagy70@yahoo.com

ISSN: 2090-7265, November 2017, Vol.7, No.4

\section{INTRODUCTION}

Hypertensive disorders of pregnancy (HDP) remain one of largest single causes of maternal and fetal morbidity and mortality 1 . Approximately $30 \%$ of HDP cases were due to chronic hypertension, while $70 \%$ of cases were due to gestational hypertension/preeclampsia ${ }^{[2]}$.

Pregnancy may induce hypertension in women who are normotensive before pregnancy and may aggravate hypertension in those who are hypertensive before pregnancy ${ }^{[3,4]}$.

Pre-eclampsia is a multisystem disorder that complicates about 3-8\% pregnancies. It is characterized by high blood pressure of $14090 / \mathrm{mmHg}$ or more along with proteinuria $(>0.3 \mathrm{gm} / 24$ hours urine collection) or any derangement in platelet count, liver enzymes or renal function tests that occur after 20 weeks of gestation ${ }^{[5]}$. The incidence is high in developing countries due to hypoproteinemia, malnutrition and poor obstetric facilities. Overall, $10-15 \%$ of maternal deaths are directly associated with pre-eclampsia and eclampsia ${ }^{[6]}$.

The risk of pre-eclampsia is two to five times more in women with maternal history of this disorder. The incidence of pre-eclampsia is high in healthy nulliparas ranging from $3 \%$ to $7 \%{ }^{[7]}$ than in nultiparas ranging from $1 \%$ to $3 \%{ }^{[8]}$.

Preeclampsia affects multiple organ systems and can lead to severe renal, hepatic, neurological, and cardiopulmonary complications and adverse perinatal outcomes (preterm birth, intrauterine growth restriction, and death) ${ }^{[9]}$. The major risk to the fetus results from decreased placental perfusion leading to decreased blood supply of oxygen and nutrients necessary for fetal growth and wellbeing ${ }^{[5]}$. 
Lipocalin-2 (LCN2), also known as oncogene $24 \mathrm{p} 3$ or neutrophil gelatinase-associated lipocalin (NGAL), is a protein that in humans increased at the end of the second trimester in women who subsequently developed preeclampsia compared to the control group ${ }^{[10]}$.

Women with preeclampsia showed elevated uric acid level in maternal blood, presumably due to decreased renal urate excretion. Various studies conducted to find out the relationship between elevated serum uric acid level and preeclampsia ${ }^{[11]}$.

Therefore, in the present study, we compared serum LCN2 and uric acid levels in women with pre-eclampsia with those of uncomplicated pregnancies to identify the potential association with the severity of preeclampsia and adverse maternal and perinatal outcomes.

\section{PATIENTS AND METHODS}

This study was conducted in, Tanta university Hospital over 9 months duration from June 2015 to March 2016, after research ethical committee approval and informed written consent taken from subjects included in this study (30256/04/ 15). Forty women with pre-eclampsia having high blood pressure of $14090 / \mathrm{mmHg}$ or more (group 1) and 20 healthy pregnant non hypertensive women (control group 2) were analyzed. This control group was well matched with the cases for maternal age, parity and gestational age. The inclusion criteria were: age range between $20-35$ years; gestational age (22 -38weeks), women with pre-eclampsia having high blood pressure of $14090 / \mathrm{mmHg}$ or more. The exclusion criteria were: Subject refusal, woman suffering from gestational hypertension, chronic kidney disease, active urinary tract infection, chronic hypertension, diabetes mellitus, chronic liver disease, cardio vascular disease and those who had infective and neoplastic pathology. All women included in the study (cases and control) on time of hospital admission were subjected to; complete history taking; clinical and blood pressure evaluation; measurements of blood urea; serum creatinine; serum uric acid; serum Lipocalin 2 by ELISA and $24 \mathrm{~h}$ collection of urine for protein level estimation. All patients were assessed for maternal and fetal well-being. The data were collected and analyzed. Mild preeclampsia was defined as blood pressure $\geq 14090 / \mathrm{mmHg}$ but less than $160110 / \mathrm{mmHg}$ with proteinuria $\geq 300 \mathrm{mg} / 24$ hours. Severe preeclampsia was defined as presence of blood pressure $\geq 160110$ / $\mathrm{mmHg}$ with urinary protein excretion of $\geq 2.0 \mathrm{gm} / 24$ hours or any of these, oliguria or $<400 \mathrm{ml}$ urine/24hours, visual disturbances, serum creatinine $\geq 1.2 \mathrm{mg} / \mathrm{dl}$, platelets less than $100,000 / \mathrm{mm} 3$, microangiopathic hemolysis. HELLP syndrome was defined as elevation of liver enzymes (AST more than $70 \mathrm{IU} / \mathrm{L}$ ), hemolysis (Lactate dehydrogenase "LDH" more than $600 \mathrm{IU} / \mathrm{L}$ ), and low platelet counts $(\leq 100,000 / \mathrm{mm} 3)$. Acute renal failure was defined as elevated creatinine of $\geq 1.5$ fold from the baseline or oliguria of $\geq 24 \mathrm{hrs}$. Proteinuria was defined as 24 hours urinary protein excretion of $\geq 300 \mathrm{mg}^{[12,13]}$.

Measurement of blood pressure was done 4 hourly, in patients of preeclampsia and control in the right arm in the supine position. Korotkoff $\mathrm{V}$ sounds were taken for measurement of diastolic blood pressure by a mercury sphygmomanometer ${ }^{[13]} .5 \mathrm{ml}$ of venous blood samples were collected from the cases and controls and allowed to clot. Samples were then centrifuged and $2 \mathrm{ml}$ of serum for routine investigation and $1 \mathrm{ml}$ were stored at $-20^{\circ} \mathrm{c}$ till assay of serum lipocalin 2 by enzyme linked immunosorbent assay (ELISA) technique, through using sandwich enzyme-linked Immunosorbent Assay Kit. (Uscn Life Science Inc. China). Serum uric acid estimation was done by nephalometry, blood urea estimation; serum creatinine estimation was done by jaffess method; and sulfosalicylic acid test used for urinary protein estimation in $24 \mathrm{~h}$ collection of urine ${ }^{[13]}$.

Alfa methyldopa was given for mild preeclampsia which is a centrally acting belongs to category B drug and is safe for the mother and fetus. Calcium channel blocker with methyldopa was given in cases of severe preeclampsia and if blood pressure wasn't controlled we add B blocker which is FDA category $\mathrm{C}$ drug. All patients were followed up to 6 weeks postpartum.

\section{Statistical analysis}

Statistical analysis was carried out using the software program Anova one-way unstacked. Quantitative data were presented as mean and standard deviation. Pearson correlation for measuring covariance of two variables divided by the product of their standard deviations measures the strength of a linear association between two variables and is denoted by r. The Receiver Operator Characteristic (ROC) curve was used for prediction of pre-eclampsia using sensitivity, specificity, accuracy and the predictive values (positive and negative).

Sensitivity: probability that the test results will be positive when the disease is present (true positive rate, expressed as a percentage); Specificity: Probability that the test results will be negative when the disease is present (true negative rate, expressed as a percentage); Positive Predictive value (PPV: probability that the disease is present when the test is positive); Negative Predictive value (NPV: probability that the disease is present when the test is negative) and accuracy is the ratio of the true positive and true negative on all patients. Result was considered significant at a $P$ value of $<0.05$ and highly significant at a $P$ value of $P<0.01$.

\section{RESULTS}

Analysis was carried out on 40 cases of preeclampsia where; 32 were mild pre-eclampsia $(80 \%)$, 
eight cases were severe pre-eclampsia (20\%) and 20 controls. The maximum number of cases was in the age range of 25- 30 years, of them $75 \%$ were in mild preeclampsia group and $50 \%$ in severe preeclampsia. Also, the maximum number of cases was primigravida in either mild $(53.125 \%)$ or severe $(50 \%)$ preeclampsia; or controls $50 \%$. The mean period of gestational age was nearly similar in pre-eclampsia cases and control $(\mathrm{p}=0.968)$.

Mean systolic blood pressure among mild preeclampsia group was $145.31+4.81 \mathrm{~mm} \mathrm{Hg}$, in severe preeclampsia group $167.50+7.56 \mathrm{mmHg}$, compared to control group $100.50+8.26 \mathrm{~mm} \mathrm{Hg}$, with statistically high significant difference between pre-eclampsia cases and control $(p<0.0001)$. Also, there was statistically high significant difference between mean diastolic blood pressure in pre-eclampsia cases and control $(p<0.0001)$; and in urine output $/ 24 \mathrm{hrs}(p<0.001)$. None of the control or mild pre-eclampsia cases showed oliguria $(>400 \mathrm{ml} / 24 \mathrm{hrs})$. Oliguria was found in $25 \%$ of severe preeclampsia cases as shown in Table (1).

All biochemical parameters in pre-eclampsia whether mild or severe showed high significant increase $(p<0.001)$ compared with control group. Lipocalin 2 and serum uric acid levels were significantly increased with severity of disease in studied group (Table 2). None of the controls showed proteinuria $<300 \mathrm{mg} / 24$ hours, in the group of mild preeclampsia $53.12 \%$ cases had proteinuria $\geq 300 \mathrm{mg} / 24$ hours and $46.88 \%$ cases had proteinuria $\geq 2 \mathrm{gm}$ in 24 hours. In the group of severe preeclampsia $35.12 \%$ cases had proteinuria $\geq 2 \mathrm{gm}$ in 24 hours and $62.50 \%$ cases showed proteinuria $>4 \mathrm{gm} / 24$ hours. This indicating increased intensity of proteinuria with the severity of disease (Table 3). Prediction of preeclampsia was done on the basis of serum LCN2 using calculation of ROC curve and area under ROC curve. Sensitivity and specificity of serum Lipocalin2 using a cut off value of $480 \mathrm{pg} / \mathrm{ml}$, for the diagnosis of preeclampsia was found to be $100 \%$ and $100 \%$ respectively, using $95 \%$ confidence interval.

The positive predictive value was $100 \%$, negative predictive value was $100 \%$, area under curve (AUC) was 1.0 and accuracy index was $100 \%$ (Tables 4, 5 and Fig. 1). There was positive correlation of lipocalin2 with various studied biochemical parameters, showing high significant correlation with uric acid and $24 \mathrm{hrs}$ protein in urine sample $(p<0.001)$ (Table 6 and Fig. 2).

Examined Cases (control; mild pre-eclampsia and severe pre-eclampsia) had 12 fetuses with intra uterine growth retardation (IUGR); 5 preterm, 1died (IUFD) the rest (42) were in good condition some of them need only incubation for increased bilirubin level. One case of control had CS (5\%), while $10(32 \%)$ cases of mild pre-eclampsia and 4 cases $(50 \%)$ of severe pre-eclampsia delivered by CS. Twenty four women of mild preeclampsia were in good condition with no complications after delivery and 8 showed complications. All women of severe pre-eclampsia showed complications and some of them were treated in ICU. Maternal and fetal complications were correlated with severity of disease in various studied groups (Table 7) and with Lipocalin2 and uric acid levels (Table 8).

Table 1 : Demographic data of the studied groups

\begin{tabular}{|c|c|c|c|c|c|}
\hline Groups & & Control & Mid Preeclampasia & $\begin{array}{c}\text { Severe } \\
\text { Preeclampasia }\end{array}$ & P Value \\
\hline \multicolumn{2}{|c|}{ Number } & 20 & 32 & 8 & \multirow{4}{*}{0.494} \\
\hline \multirow{3}{*}{ Age years } & $<25$ & $4(20 \%)$ & $6(18.75 \%)$ & $3(37.5 \%)$ & \\
\hline & $25-30$ & $14(70 \%)$ & $24(75 \%)$ & $4(50 \%)$ & \\
\hline & $>30$ & $2(10 \%)$ & $2(6.25 \%)$ & $1(12.5 \%)$ & \\
\hline Mean & & $\mathrm{w}$ & $26.80+3.22$ & $27.25+4.26$ & 0.924 \\
\hline Gravida & $\begin{array}{l}1 \\
2 \\
3 \\
4\end{array}$ & $\begin{array}{cc}10 & (50 \%) \\
6 & (30 \%) \\
3 & (15 \%) \\
1 & (5 \%)\end{array}$ & $\begin{array}{c}17(53.125 \%) \\
8(25 \%) \\
5(15.6 \%) \\
2(6.25)\end{array}$ & $\begin{array}{c}4(50 \%) \\
2(25 \%) \\
1(12.5 \%) \\
1(12.5 \%)\end{array}$ & 0.217 \\
\hline \multirow[b]{2}{*}{ SBP(mmHg) } & gestation & $29.45+5.20$ & $29.68+5.25$ & $30.00+5.78$ & 0.968 \\
\hline & $\begin{array}{c}\text { Range } \\
\text { Mean + SD }\end{array}$ & $\begin{array}{c}90-110 \\
100.50+8.26\end{array}$ & $\begin{array}{c}140-155 \\
145.41+4.77\end{array}$ & $\begin{array}{c}160-180 \\
167.50+7.56\end{array}$ & $<0.0001$ \\
\hline DBP(mmHg) & $\begin{array}{c}\text { Range } \\
\text { Mean + SD }\end{array}$ & $\begin{array}{c}60-80 \\
70.90+5.13\end{array}$ & $\begin{array}{c}90-115 \\
92.47+5.52\end{array}$ & $\begin{array}{c}100-120 \\
108.13+7.53\end{array}$ & $<0.0001$ \\
\hline & & $20(100 \%)$ & $32(100 \%)$ & $\begin{array}{l}6(75 \%) \\
2(25 \%)\end{array}$ & $<0.001$ \\
\hline
\end{tabular}

$\mathrm{SD}=$ standard deviation; $\mathrm{BP}=$ blood pressure; $\mathrm{SBP}=$ systolic blood pressure; $\mathrm{DBP}=$ Diastolic blood pressure 
Table 2: Biochemical parameters of the studied groups

\begin{tabular}{|c|c|c|c|c|}
\hline Items & $\operatorname{Control}(\mathrm{N}=20)$ & $\begin{array}{l}\text { Mid Preeclampasia } \\
\qquad(\mathrm{N}=32)\end{array}$ & $\begin{array}{l}\text { Severe Preeclampasia } \\
\qquad(\mathrm{N}=8)\end{array}$ & P Value \\
\hline $\begin{array}{l}\mathrm{Hb}(\mathrm{gm} / \mathrm{dl}) \\
\text { Range } \\
\text { Mean }+\mathrm{SD}\end{array}$ & $\begin{array}{c}9-11.8 \\
10.38+0.96\end{array}$ & $\begin{array}{c}\text { 6.8-11 } \\
9.17+1.18\end{array}$ & $\begin{array}{c}6.8-10.4 \\
9.05+1.03\end{array}$ & 0.001 \\
\hline $\begin{array}{l}\text { Platelet count } \\
\text { (thousands/mm3) } \\
\text { Range } \\
\text { Mean + SD }\end{array}$ & $\begin{array}{c}150-285 \\
210.25+40.99\end{array}$ & $\begin{array}{c}80-200 \\
118.00+31.36\end{array}$ & $\begin{array}{c}85-110 \\
98.75+11.57\end{array}$ & $<0.001$ \\
\hline $\begin{array}{l}\text { Serum uric acid }(\mathrm{mg} / \mathrm{dl}) \\
\text { Range } \\
\text { Mean }+ \text { SD }\end{array}$ & $\begin{array}{c}3.40-4.5 \\
2.88+0.56\end{array}$ & $\begin{array}{c}4.3-7.8 \\
6.69+1.08\end{array}$ & $\begin{array}{c}6.5-11.1 \\
8.65+1.49\end{array}$ & $<0.001$ \\
\hline $\begin{array}{l}\text { Serum urea } \\
(\mathrm{mg} / \mathrm{dl}) \\
\text { Range } \\
\text { Mean }+\mathrm{SD}\end{array}$ & $\begin{array}{c}18-45 \\
26.45+6.64\end{array}$ & $\begin{array}{c}15-60 \\
37.91+16.07\end{array}$ & $\begin{array}{c}35-90 \\
54.38+18.98\end{array}$ & $<0.001$ \\
\hline $\begin{array}{l}\text { Serum Creatinine } \\
(\mathrm{mg} / \mathrm{dl}) \\
\text { Range } \\
\text { Mean }+\mathrm{SD}\end{array}$ & $\begin{array}{l}0.70-1.3 \\
0.810 .15\end{array}$ & $\begin{array}{c}0.70-2.8 \\
1.66+0.68\end{array}$ & $\begin{array}{c}0.90-2.9 \\
2.26+0.66\end{array}$ & $<0.001$ \\
\hline $\begin{array}{l}\text { S. Bilirubin }(\mathrm{mg} / \mathrm{dl}) \\
\text { Range } \\
\text { Mean }+ \text { SD }\end{array}$ & $\begin{array}{c}0.4-0.9 \\
0.52+0.14\end{array}$ & $\begin{array}{c}0.5-1.5 \\
1.06+0.33\end{array}$ & $\begin{array}{c}0.6-2 \\
1.66+0.45\end{array}$ & $<0.001$ \\
\hline $\begin{array}{l}\text { S AST (U/L) } \\
\text { Range } \\
\text { Mean }+ \text { SD }\end{array}$ & $\begin{array}{c}12-34 \\
20.95+7.49\end{array}$ & $\begin{array}{c}22-38 \\
30.56+6.03\end{array}$ & $\begin{array}{c}28-48 \\
40.00+8.21\end{array}$ & $<0.001$ \\
\hline $\begin{array}{l}\text { Urinary protein level } \\
\text { in } 24 \mathrm{hrs}(\mathrm{mg} / 24 \mathrm{hr}) \\
\text { Range } \\
\text { Mean + SD }\end{array}$ & $\begin{array}{c}90-125 \\
104.70+9.7\end{array}$ & $\begin{array}{c}330-3400 \\
1639.9+873.0\end{array}$ & $\begin{array}{c}3000-5600 \\
4290.0+921.0\end{array}$ & $<0.001$ \\
\hline $\begin{array}{l}\text { Serum lipocalin } 2 \text { )ng/ml) } \\
\text { Range } \\
\text { Mean }+ \text { SD }\end{array}$ & $\begin{array}{l}200-440 \\
293+69\end{array}$ & $\begin{array}{c}480-7320 \\
4975+1909\end{array}$ & $\begin{array}{l}7320-10755 \\
9597+1309\end{array}$ & $<0.001$ \\
\hline
\end{tabular}

$\mathrm{AST}=$ Aspartate aminotransferase

Table 3: Proteinuria in various studied groups

\begin{tabular}{lccc}
\hline $\begin{array}{l}\text { Protein level in } 24 \mathrm{hrs} \\
(\mathrm{mg} / 24 \mathrm{hr})\end{array}$ & $\begin{array}{c}\text { Control } \\
(\mathrm{N}=20)\end{array}$ & $\begin{array}{c}\text { Mild preeclampsia } \\
(\mathrm{N}=32)\end{array}$ & $\begin{array}{c}\text { Severe preeclampsia } \\
(\mathrm{N}=8)\end{array}$ \\
\hline$<300 \mathrm{mg}$ & $20(100 \%)$ & $0(0.00 \%)$ & $0(0.00 \%)$ \\
$>300 \mathrm{mg}$ & $0(0.00 \%)$ & $17(53.12 \%)$ & $0(0.00 \%)$ \\
$>2 \mathrm{gm}$ & $0(0.00 \%)$ & $15(46.88 \%)$ & $3(35.12 \%)$ \\
$>4 \mathrm{gm}$ & $0(0.00 \%)$ & $0(0.00 \%)$ & $5(62.50 \%)$ \\
\hline
\end{tabular}


Table 4: Test Result Variable(s): Lipocalin2

\begin{tabular}{lcccc}
\hline & & \multicolumn{2}{c}{ Asymptotic 95\% Confidence Interval } \\
\hline Area & Std. Error(a) & Asymptotic Sig.(b) & Lower Bound & Upper Bound \\
1.000 & .000 & .000 & 1.000 & 1.000 \\
\hline
\end{tabular}

$\mathrm{a}$-Under the nonparametric assumption. $\mathrm{b}$ - Null hypothesis: true area $=0.5$

Table 5: Area under the curve, sensitivity, specificity, predictive values and accuracy

\begin{tabular}{lccccccc}
\hline & Cutoff & AUC & Sensitivity & Specificity & PPV & NPV & Accuracy \\
\hline Lipocalin 2 & 480 & 1.0 & 100 & 100 & 100 & 100 & 100 \\
& & & & & & & \\
\hline
\end{tabular}

AUC =Area under Curve; PPV=positive predictive value; NPV=negative predictive value.

Table 6: Correlation between Lipocalin2 and biochemical parameters (uric acid, urea, creatinine, serum Bilirubin, AST and 24 hrs protein in urine sample) in pre-eclampsia cases

\begin{tabular}{c|cc}
\hline & \multicolumn{2}{c}{ Lipocalin 2 } \\
\hline Uric acid & r. & $\mathrm{p}$ \\
Urea & 0.503 & $0.001^{*}$ \\
Creatinine & 0.309 & 0.052 \\
Bilirubin & 0.450 & $0.004^{*}$ \\
AST & 0.383 & $0.015^{*}$ \\
24 hrs protein in urine sample & 0.313 & $0.049^{*}$ \\
\hline
\end{tabular}

AST $=$ Aspartate aminotransferase

Table 7: Correlation between fetal and maternal outcome in various studied groups

\begin{tabular}{lccc}
\hline Fetal outcome & $\begin{array}{c}\text { Control } \\
(\mathrm{N}=20)\end{array}$ & $\begin{array}{c}\text { Mild preeclampsia } \\
(\mathrm{N}=32)\end{array}$ & $\begin{array}{c}\text { Severe preeclampsia } \\
(\mathrm{N}=8)\end{array}$ \\
\hline Bad & $1(5 \%)$ & $10(31.25 \%)$ & $7(87.5 \%)$ \\
Good & $19(95 \%)$ & $22(68.75 \%)$ & $1(12.5 \%)$ \\
& & & $0(0.00 \%)$ \\
Maternal outcome & $20(100 \%)$ & $24(75 \%)$ & $8(100 \%)$ \\
No complications & $0(0.00 \%)$ & $8(25 \%)$ & $1(12.5 \%)$ \\
Complications & & & $2(25 \%)$ \\
Pulmonary edema & & $3(9.4 \%)$ & $2(25 \%)$ \\
admitted to ICU & $0(0.00 \%)$ & $4(12.5 \%)$ & $1(12.5 \%)$ \\
Accidental hemorrhage & $0(0.00 \%)$ & $1(3.12 \%)$ & $2(25 \%)$ \\
HELLP & $0(0.00 \%)$ & $0(0.00 \%)$ & $0(0.00 \%)$ \\
ARF & $0(0.00 \%)$ & & \\
Eclampsia & $0(0.00 \%)$ & & \\
\hline
\end{tabular}

ICU= Intensive care unit; HELLP= Hemolysis, Elevated Liver Enzymes, Low Platelets; ARF =Acute Renal Failure 
Table 8: Correlation of Lipocalin2 and serum uric acid with maternal and fetal outcome

\begin{tabular}{|c|c|c|c|c|}
\hline \multirow{2}{*}{$\begin{array}{l}\text { Items } \\
\text { Lipocalin2 } \\
(\mathrm{n}=60)\end{array}$} & \multicolumn{2}{|c|}{ Fetal outcome } & \multicolumn{2}{|c|}{ Maternal out come } \\
\hline & $\operatorname{Bad}(\mathrm{n}=18)$ & Good $(n=42)$ & Complications $(n=16)$ & $\begin{array}{l}\text { No Complications } \\
\qquad(\mathrm{n}=44)\end{array}$ \\
\hline$<440 \mathrm{ng} / \mathrm{ml}$ & 1 IUGR (5.55\%). & $19(45.23 \%)$ & $0(0.00)$ & $20(45.45 \%)$ \\
\hline$>480 \mathrm{ng} / \mathrm{ml}$ & $\begin{array}{c}\text { 7IUGR }(38.88 \%) \\
\text { 3Preterm }(16.66 \%)\end{array}$ & $22(45.23 \%)$ & $\begin{array}{c}\text {-3Pulmonary } \\
\text { edema }(18.75 \%) \\
\text {-4Accidental } \\
\text { hemorrhages }(25 \%) \\
\text {-1 HELLP }(6.25 \%)\end{array}$ & $24(54.54 \%)$ \\
\hline$>7320 \mathrm{ng} / \mathrm{ml}$ & $\begin{array}{l}4 \text { IUGR }(22.22 \%) \\
2 \text { Preterm }(11.11 \%) \\
1 \text { IUFD }(5.55 \%)\end{array}$ & $1(9.52 \%)$ & $\begin{array}{c}\text {-1Pulmonary } \\
\text { edema }(6.25 \%) \\
\text {-2Accidental } \\
\text { hemorrhages }(12.5 \%) \\
\text {-2 HELLP }(12.5 \%) \\
\text {-1 ARF }(6.25 \%) \\
-2 \text { Eclampsia }(12.5 \%)\end{array}$ & $(0.00)$ \\
\hline Uric acid & $\operatorname{Bad}(n=18)$ & Good $(n=42$ & Complications $(n=16)$ & No Complications $(n=44)$ \\
\hline$<5 \mathrm{mg} / \mathrm{dl}$ & $\begin{array}{l}1 \text { IUGR }(5.55 \%) \\
1 \text { Preterm }(5.55 \%)\end{array}$ & $27(64.29 \%)$ & $\begin{array}{l}\text { - } 1 \text { Pulmonary } \\
\text { edema }(6.25 \%)\end{array}$ & $28(63.63 \%)$ \\
\hline$<5 \mathrm{mg} / \mathrm{dl}$ & $\begin{array}{c}5 \text { IUGR }(27.77) \\
2 \text { preterm }(11.11 \%)\end{array}$ & $9(21.42 \%)$ & $\begin{array}{c}-2 \text { Pulmonary } \\
\text { edema }(12.5 \%) \\
-3 \text { accidental } \\
\text { hemorrhages }(18.75 \%) \\
--1 \text { HELLP }(6.25 \%)\end{array}$ & $12(27.27 \%)$ \\
\hline$>7 \mathrm{mg} / \mathrm{dl}$ & $\begin{array}{l}6 \text { IUGR }(33.33 \%) \\
2 \text { preterm }(11.11 \%) \\
1 \text { IUFD }(5.55 \%)\end{array}$ & $6(14.29 \%)$ & $\begin{array}{c}\text {-1Pulmonary } \\
\text { edema }(6.25 \%) \\
-3 \text { Accidental } \\
\text { hemorrhages }(18.75 \%) \\
-2 \text { HELLP }(12.5 \%) \\
-1 \text { ARF }(6.25 \%) \\
-2 \text { Eclampsia }(12.5 \%)\end{array}$ & $4(9 \%)$ \\
\hline
\end{tabular}

\section{ROC Curve}

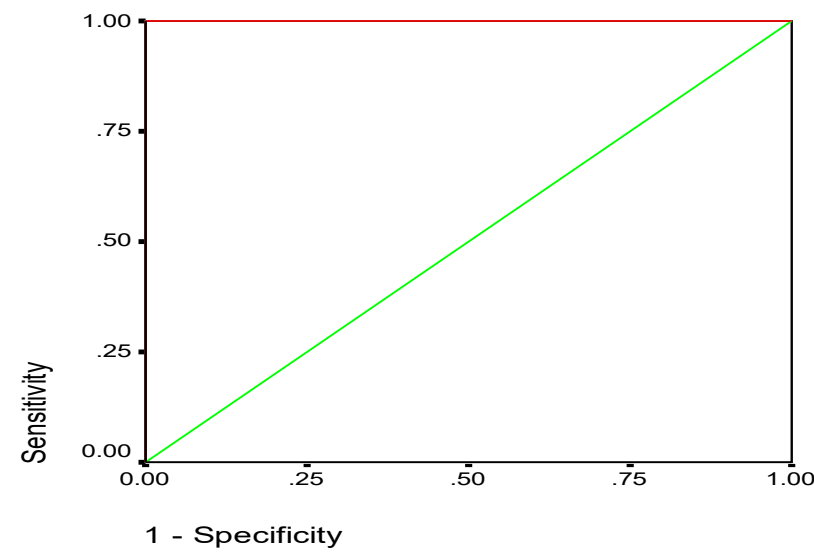

Fig. 1: ROC curve analysis showing sensitivity 100\%, specificity $100 \%$ at cutoff value $480 \mathrm{ng} /$ $\mathrm{ml}$ of Lipocalin2. 

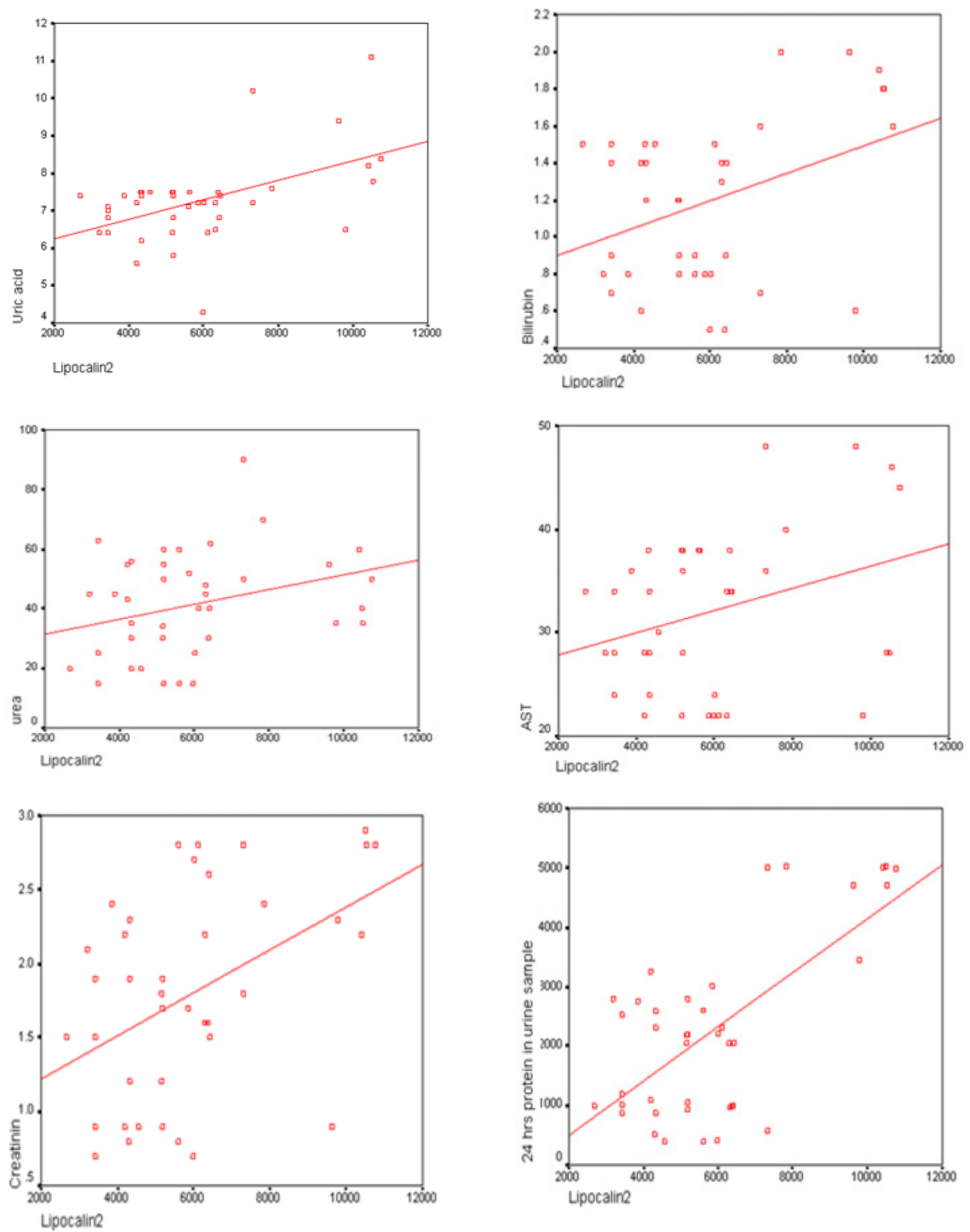

Fig. 2: Positive correlation of Lipocalin2 with various studied biochemical parameters (uric acid, urea, creatinine, serum bilirubin, AST and 24 hrs protein in urine sample) in pre-eclampsia cases 


\section{DISCUSSION}

Pre-eclampsia a hypertensive disorders complicating pregnancy (HDP) is a major disease which seriously endangers the safety of mother and fetus during pregnancy. Pre-eclampsia affects approximately 28- percent of pregnancies worldwide and is considered as the major cause of maternal and fetal morbidity and mortality ${ }^{[14]}$.Thus major efforts are being made to identify effective biomarkers for the risk assessment and disease management.

An ideal biomarker of pre-eclampsia is the one that would allow an accurate prediction during the first trimester as it offers a wide range for effective treatment that may help in complete recovery or reduce the severity of disease ${ }^{[15]}$.

The present study mainly focuses on biomarker Lipocalin-2 and hyperuricemia in predicting the severity of pre-eclampsia and maternal and perinatal outcome. Analysis was carried out on 40 women with pre-eclampsia (32 mild pre-eclampsia and eight severe pre-eclampsia) and 20 healthy pregnant non hypertensive women. In this study the maximum number of cases was in the age range of $25-30$ years and primigravida with nearly similar mean period of gestational age in all studied cases (preeclampsia and control). Our findings coincided with those of Rosaria et al ${ }^{[16]}$ who found that age wise distribution, in cases of preeclampsia was similar to controls. We found statistically significant difference between mean systolic and diastolic blood pressure in pre-eclampsia cases and control, where maximum severity was found in the group of severe preeclampsia $(p<0.0001)$. Similarly, Sachan et al ${ }^{[17]}$ showed that preeclampsia in systolic blood pressure and diastolic blood pressure was positively correlated with severity of disease.

In the present study none of the control or mild pre-eclampsia cases showed oliguria $(>400 \mathrm{ml} / 24 \mathrm{hrs})$. Oliguria was found in $25 \%$ of severe preeclampsia cases, with statistically significant difference between preeclampsia cases and control $(p<0.001)$. This was comparable to study carried out by various authors ${ }^{[18]}$ in which oliguria was found in $9.43 \%$ women with hypertensive disorders of pregnancy, Sachan et al ${ }^{[17]}$ showed oliguria in $18.07 \%$ cases of severe preeclampsia and $20 \%$ cases of eclampsia, with statistically significant difference $(p<0.001)$.

We detected in the present study significantly increasing mean levels of serum urea and creatinine in preeclampsia cases as compared to controls $(p<0.001)$, and constantly increasing levels with the severity of disease, as had been found by Gebhard et al ${ }^{[19]}$. In the group of severe preeclampsia $35.12 \%$ cases had proteinuria $\geq 2 \mathrm{gm}$ in 24 hours and $62.50 \%$ cases showed proteinuria $>4 \mathrm{gm} / 24$ hours. This indicating increased intensity of proteinuria with the severity of disease.

In our study, ROC curve of Lipocalin 2 using a cutoff value of $480 \mathrm{ng} / \mathrm{ml}$ showed 100\%sensitivity, 100\% specificity of serum, for the diagnosis of preeclampsia at $95 \%$ confidence interval. The positive predictive value was $100 \%$, negative predictive value was $100 \%$, area under curve (AUC) was 1.0 and accuracy index was $100 \%$. These results slightly differed, from those obtained by Sachan et al ${ }^{[17]}$ who detected positive predictive value $98.58 \%$, negative predictive value $90.63 \%$, area under curve (AUC) was $95.72 \%$ and accuracy index was $97.11 \%$ at a cut-off value of $545 \mathrm{ng} / \mathrm{ml}$.

Serum Lipocalin 2 showed positive correlation with serum urea $(r=0.309)$, serum creatinine $(r=0.450)$ and proteinuria. Therefore, Lipocalin 2 might be considered a novel biomarker for early prediction of preeclampsia and also useful in assessment of disease severity. D'Anna et al ${ }^{[20]}$ showed positive correlation of Lipocalin2 with the systolic, diastolic blood pressure and with proteinuria and considered Lipocalin2 a reliable biomarker for early prediction of pre-eclampsia.

In the present study, 24(40\%) women went into spontaneous labor while the rest were induced. Among those who delivered, 15 (25\%) underwent caesarean section while the remaining delivered vaginally. The most common complication associated with pre-eclampsia in this study was accidental hemorrhage $6(15 \%)$. Other complications associated were pulmonary edema $4(10 \%)$, HELLP $3(7.5 \%)$, eclampsia 2(5\%) and ARF1 (2.5). There were no cases of maternal mortality. Such findings were comparable with those of Aabidha et al ${ }^{[21]}$ who showed in their study that the most common complication in preeclampsia was antepartum hemorrhage (13.97\%), followed by post partum hemorrhage $(10.75 \%)$ and eclampsia $(5.37 \%)$, with no maternal mortality.

The most common neonatal complications met with in the present study of pre-eclampsia cases were IUGR $12(30 \%)$, preterm $5(12.5 \%)$ IUFD 1(2.5). Aabidha et al ${ }^{[21]}$ showed that pre-maturity $(23.65 \%)$ was the most common neonatal complications followed by low birth weight $(7.52 \%)$ and intra uterine growth restriction $(9.67 \%)$ in their studied pre-eclampsia cases. These neonatal complications could result from decreased placental perfusion in pre-eclampsia leading to decreased blood supply of oxygen and nutrients necessary for fetal growth and wellbeing. 
In the present study, serum uric acid levels were significantly raised in preeclampsia cases as compared to controls $(p<0.001)$. The values of serum uric acid when compared with mean serum Lipocalin 2 level, showed a positive correlation $(\mathrm{r}=0.503)$. These results coincided with those of Sachan et al ${ }^{[17]}$.

However, results are controversial regarding hyperuricemia. Several studies said that serum uric acid is a reliable predictor of preeclampsia ${ }^{[22]}$, others suggested that the predictive value of serum uric acid is relatively poor for diagnosis and prognosis of preeclampsia ${ }^{[23,24]}$. Therefore, prediction of preeclampsia could be better evaluated by serum Lipocalin 2 which is a sensitive indicator of severity of the disease. The time of onset of pre-eclampsia is of great importance in determining the final outcome of fetus because the only treatment for such disorder is earliest delivery that may endanger fetal outcome.

Various studies suggested that elevated serum uric acid in pregnancy is not only a valuable biomarker for pre-eclampsia, but it may also have a contributory role in pathogenesis of maternal and fetal manifestation ${ }^{[25]}$. We found in our study increased fetal complications with rising of serum uric acid level from $5 \mathrm{mg} / \mathrm{dl}$ to more than $>7 \mathrm{mg} / \mathrm{dl}$. This coincided with some studies suggesting that the degree of elevation of serum uric acid level correlates with the severity of maternal syndrome and fetal morbidity ${ }^{[26]}$.Tejal and Astha $^{[27]}$ showed that the time at which serum uric acid concentration begins to rise is an approximate indicator of the time of onset of the preeclampsia. They showed the value of measuring serum uric acid in hypertensive pregnancy between 24 to 32 weeks of gestation. Low values indicate a good prognosis for the fetus. Rising or high values at this time indicate high-risk cases which are better managed and treated in hospital.

\section{CONCLUSION}

In conclusion, Lipocalin2 could be considered a novel biomarker for early prediction of preeclampsia and also useful in assessment of disease severity. Measurement of serum uric acid is recommended beside other biomarkers used in pre-eclampsia as it is of great diagnostic and prognostic value for fetus to assess the severity of morbidity, identifying those fetuses that are likely to have IUGR and high perinatal mortality. Additional studies involving larger populations are needed to further investigate the role of these biomarkers in the diagnosis and prediction of preeclampsia to avoid serious maternal complications and give the best possible chance of fetal survival.

\section{CONFLICT OF INTEREST}

There is no conflict of interest.

\section{REFERENCES}

1. Khan KS, Wojdyla D, Say L, Gulmzoglu AM, van look PF. Who analysis of cauises of maternal death, a systematic review. Lancet $2006 ; 367: 1066-1074$.

2. Matthys LA, Coppage KH, Lambers DS, Barton JR, Sibai BM. Delayed postpartum preeclampsia: an experience of 151 cases. Am J Obstet Gynecol 2004;190(5):1464-1466.

3. Agustin CA \& Belizam JM. Risk factors for preeclampsia in a large cohort of Latin American and Caribbean Women. British J Obstet Gynecol 2000; 107(1):75 -83.

4. Amanda M, Cotter Anne M, Molloy Scott JM, Daly SF. Significance of hyperuricemia in preeclampsia. Am J Obstet Gynecol 2003; 189:391 -96.

5. Berkane N. Gestational hypertensions: Definitions and consequences in outcome of pregnancy. Ann Fr Anesth Rènim 2010; 29:e 1-6. [PubMed]

6. Carty DM, Delles C, Dominiczak AF. Preeclampsia and future maternal health. J Hypertension. 2010; 28:1349-55. [PubMed]

7. Sibai B, Dekker G, Kupferminc M. Preeclampsia. Lancet 2005; 365:785-99. [PubMed]

8. Uzan J, Carbonnel M, Piconne O, Asmar R, Ayoubi JM. Pre-eclampsia: Pathophysiology, diagnosis and management. Vasc Health Risk Manag. 2011; 7:467-74. [PMC free article][PubMed].

9. Livingston JR, Payne B, Brown M, Roberts JM, Anne-Marie Côté AM, Magee LA, Dadelszen Pv. Uric Acid as a Predictor of Adverse Maternal and Perinatal Outcomes in Women Hospitalized With Preeclampsia. JOGC 2014; 870- 877.

10. Giasson J, Li GH, Chen Y. Neutrophil gelatinaseassociated lipocalin (NGAL) as a new biomarker for non-acute kidney injury (AKI) diseases. Inflamm Allergy Drug Targets 2011; 10:272-82. [PubMed]

11. Danna R, Baviera G, Scilipoti A, Loonardi I, Leo R. 'The clinical utility of serum uric acid measurements in preeclampsia and transient hypertension in pregnancy. Panminerva Med 2000; 42(2):101-03. 
12. Shyam R, Patel ML, Gaurav A, Angwar R. Serum Neutrophil Gelatinase-Associated Lipocalin: Predictor of Pre-Eclampsia, Eclampsia and Its Correlation with Severity of Disease. International Journal Medicine and Medical Sciences 2013; 46 : 1170 -1178, ISSN:2051- 5731, Issue.2

13. Patel ML, Sachan R, Gangwar R, Sachan P, Natu SM. Correlation of serum neutrophil gelatinaseassociated lipocalin with acute kidney injury in hypertensive disorders of pregnancy. International Journal of Nephrology and Renovascular Disease 2013:6 181-186

14. Carty DM, Delles C, Dominiczak AF: Novel biomarkers for predicting preeclampsia. Trends Cardiovasc Med. 2008; 18:186-94. [PMC free article] [PubMed]

15. Nicolaides KH, Bindra R, Turan OM, Chefetz L, Sammar M, Meiri H, et al. A novel approach to first-trimester screening for early pre-eclampsia combining serum PP-13 and Doppler ultrasound. Ultrasound Obstet Gynecol 2006;27:13-7. [PubMed]

16. Rosaria D Anna, Giovanni Baviera, Domenico Giordino , Giovanna Todarello, Francesco Coredo, Stephania recupero, davide bolignano. Neutrophil gelatinase- associated lipocalin serum evalutation through normal pregnancy and in pregnancies complicated by preeclampsia Acta Obstetricia et Gynecologica Scandinavica $2010 ; 89$ (2): $275-278$.

17. Sachan R, Patel ML, Gaurav A, Angwar R. Serum Neutrophil Gelatinase-Associated Lipocalin: Predictor of Pre-Eclampsia, Eclampsia and Its Correlation with Severity of Disease. International Journal Medicine and Medical Sciences, ISSN: 2013; 46:20515731-, Issue.2 1170 -78.

18. Jai Prakash, Rubina Vohra, IK Pandey, Shashidhar Shree Niwas, SK Behura. Usha SinghSpectrum of Kidney Diseases in Patients with Preeclampsiaeclampsia. JAPI. 2010; 58:543- 546.

19. Gebhard Wagener, Moury Minhaz, Fallon A. Urinary neutrophil gelatinase- associated lipocalin as a marker of acute kidney injury after orthotopic liver transplantation. Nephrol Dial Transplant 2011; 0:1- 7 .

20. D'Anna R, Baviera G, Giordano D, Todarello G, Russo S, Recupero S, et al. Neutrophil gelatinaseassociated lipocalin serum evaluation through normal pregnancy and in pregnancies complicated by preeclampsia. Acta Obstet Gynecol Scand 2010;89:275-8. [PubMed]

21. Aabidha PM, CherianAG, PaulE, HelanJ. Maternal and fetal outcome in pre-eclampsia in a secondary carehospital in South India. JFamily MedPrim Care. 2015 ; 4(2): 257-260. doi: 10.4103-2249/ 4863.154669 .

22. Gianni Bellomo, Sandro Venanzi, Paolo Saronio, Claudio Verdura, Pier Luca Narducci. Prognostic Significance of Serum Uric Acid in Women with Gestational Hypertension Hypertension 2011; HY PERTENSIONAHA.111.177212published online before print August 292011

23. Cnossen JS, de Ruyter-Hanhijarvi H, van der Post JA, Mol BW; Accuracy of serum uric acid determination in predicting pre-eclampsia: a systematic review. Acta Obstet Gynecol Scand 2006; 85: 519- 525 .

24. Thangaratinam S, Ismail KM, Sharp S, Coomarasamy A, Khan KS; Accuracy of serum uric acid in predicting complications of preeclampsia: a systematic review. BJOG 2006; 113 : 369-378.

25. Bainbridge SA, Roberts JM. Uric acid as a pathogenic factor in preeclampsia. Placenta 2008; 29S: 67-72.

26. Sagen N, Haram K, Nilsen ST. Serum urate as a predictor of fetal outcome in severe pre-eclampsia. Acta Obstet Gynecol Scand 1984; 63: 71- 75.

27. Tejal P and Astha D. Relationship of Serum Uric Acid Level to Maternal and Perinatal Outcome in Patients with Hypertensive Disorders of Pregnancy. Gujarat Medical Journal 2014; 69 (2): $45-47$. 